\title{
China and Democracy
}

Sources and Resources

Hélène Piquet

\section{(2) OpenEdition}

\section{Journals}

Electronic version

URL: http://journals.openedition.org/chinaperspectives/4750

DOI: 10.4000/chinaperspectives. 4750

ISSN: 1996-4617

\section{Publisher}

Centre d'étude français sur la Chine contemporaine

\section{Printed version}

Date of publication: 1 December 2008

Number of pages: $96-101$

ISSN: 2070-3449

\section{Electronic reference}

Hélène Piquet, « China and Democracy », China Perspectives [Online], 2008/4 | 2008, Online since 01 December 2011, connection on 24 September 2020. URL : http://journals.openedition.org/ chinaperspectives/4750; DOI : https://doi.org/10.4000/chinaperspectives.4750

(C) All rights reserved 


\title{
$\geq$ China and Democracy
}

\author{
Sources and Resources
}

HÉLĖNE PIQUET

$\mathrm{T}$ he contributors to La Chine et la démocratie, edited by Mireille Delmas-Marty and Pierre-Étienne Will, address the following question: "To what extent does Chinese political culture, in both its historical dimension and in a larger sense Chinese culture in general, contain elements capable of adjusting to the values and practices of modern democratic liberalism offered as an example to China over the past century or more (...)." (1)

The book, made up of 21 chapters grouped into six sections, takes the reader from the past to the present, with some authors contributing more than one chapter. The chapters by Anne Cheng and Pierre-Étienne Will in the first section, "Tradition and reconstruction," challenge some of the received ideas on China that feed images of the country in the Western imagination. Will retraces contrasting images of China in nineteenth century European authors' works that oscillate between despotism and democracy, adding nuance to the usual perception that the eighteenth century was characterised by Sinophilia and the nineteenth by Sinophobia. Cheng, for her part, applies a systematic and critical analysis to research trends focused on the idea of "seeds of democracy in Confucian tradition." She traces the origins of these currents, stressing the need for a more specific definition of "Confucianism," which is often used in an essentialist and imprecise way.

Will and Jérôme Bourgon share the second section, which is devoted to imperial institutions. Will deals with curbs on excessive power under the Ming dynasty, presenting three censorship missions and a case study from Emperor Wan Li's rule. He makes a nuanced analogy with the constitutional control developed in France, and sheds light on the normative bases that could invoke censorship in the implementation of control functions. Will aims to establish that several control institutions at the time "functioned quite well alongside the notion of Constitution" as understood today. Bourgon offers a re-examination of many received ideas on China and its supposed ignorance of the notion of "law" as advanced by some European and American Sinologists. He focuses on the principles of legality and rule of law in the context of their importance to the question of democracy. Bourgon notes that China adopted "the first judicial system in the modern sense of the term" back in the third century. He deals with the question of whether China was the originator of the principle of legality of punishment, detailing several elements from the history of Chinese law in a comparative perspective, and he forcefully refutes the idea that China was unaware of rule of law. He concludes with a call for overcoming several epistemological obstacles, such as the concept of "oriental despotism," in order to understand law in imperial China.

The third section deals with transitions, with four contributions dealing with law at different stages from the end of Empire to the Republic. Bourgon studies the emergence of the legal profession in the "ancien régime" between 1740 and 1930, and establishes the existence of a veritable epistemic community of jurists toward the end of the imperial era. The Tongzhi restoration marks a turning point in this community's formation. While in the political sphere this period is associated with the last stages of Chinese conservatism, Bourgon shows that it was in fact rich in innovations for the evolution of Chinese law and legal professions, notably in the establishment of magistrates and the Westernisation of China's legal system.

Zhang Ning examines the handling of the death penalty, banditry, and special practices, focusing on several penal codes from the late Qing and Republican periods. She stresses the need to understand the drawn-out internal turmoil of China's history over the last 150 years in order to grasp the factors behind the "death penalty culture" associated with China today. The special penal regime centred

1. Mireille Delmas-Marty and Pierre-Étienne Will (eds.), La Chine et la démocratie, Paris, Fayard, p. 8 . 
around the judicial category fei, rendered as "banditry," reflects the authorities' intense concern over a phenomenon that seriously threatened public order. This new category emerged in the mid-nineteenth century, as trouble a time as China ever knew, and the Republic continued to be haunted by the bandit figure. A dual legal regime resulted: on the one side, an ordinary penal system, codified and practised by the state, and on the other, special penal procedures contained in legislation meant to be "temporary" but in fact used over extended periods. This penal law heritage continues to influence not only the practice but also public opinion of the death penalty.

Joël Thoraval studies the evolution of the notion of freedom as developed by Kant, stressing the changes the concept underwent its transfer to the Chinese context through its appropriation by Liang Qichao. In particular, he employs a vast terminological study to retrace how and why this notion became embedded with undeniable Buddhist influences. In passing, he recalls Japan's critical role as transmitter of several Western concepts. Thoraval underlines the complexity of the circulation of norms and concepts when received in cultural, social, and political contexts much different from those which they originated.

In two texts covering consecutive periods, Xiaohong XiaoPlanes deals with two central aspects of Chinese political life between 1908 and 1949. Examining the period from 1908 to 1914, she highlights the role of local elites in attempts to instil political modernity throughout the country. Among other things, she draws attention to little known changes such as the alliance of literary activists with industrialists and merchants, which gave rise to "neo-Confucian" principles that richly favoured the state's reconstruction. She refutes culturalist arguments that see democracy as "a typically Western political system, unsuited to Chinese realities," and concludes by pointing out the richness of local resources in political matters within the Chinese tradition. XiaoPlanes' second text concerns the transfer of constitutionalism in China between 1908 and 1949, and concentrates on Chinese visions of the constitutional state that nourished the formulation - and when the situation arose, the application of the constitution in the highly-charged political context of the times. The author stresses the importance of the receiving country's context in the transfer of laws; in China's case, especially, the issue of relations between the centre and "territorial entities."

Will's text is on Chinese contributions to the Universal Declaration of Human Rights (UDHR). He retraces the UDHR's drafting process and introduces the Chinese indi- viduals who worked on the project under the aegis of the United Nations Human Rights Commission. Will sheds light on the stands taken by each of them, and documents their contributions to both the content and the debate over the declaration. The text contains two elements of particular relevance to the research theme of the book: on the one hand, the successive Chinese members who took part in the drafting adhered to the notion of "human rights," while on the other hand, Chinese debates on the issue took place "outside the Chinese tradition," and many ideas put forward in China "coincided perfectly" with UDHR principles.

Yves Chevrier wrote the first two chapters of the fourth section, entitled "Uses of the concept of democracy in the twentieth century." Although distinct, the two chapters form an inseparable whole, the common element being the identification of many epistemological obstacles relating to readings from the periods 1890-1915 and 1915-1937 in Sinology. In the first of the two chapters, he shows a desire to rehabilitate the political and cultural transformations between 1890 and 1915. Chevrier points out that they were devalued as "incomplete," given the Westernisation process in that period. He attributes this devaluation to the importance of the transformations that sought to question the "dominant account" negating the ability of the "political form" to change under empire. He postulates that a culture at once Chinese, modern, and diversified had in fact taken shape in China before 1915 and the "new knowledge" movement. In re-evaluating this period, it should be understood that the supposed exclusivity of Chinese culture and democracy did not exist. This rupture came in 1915, following the iconoclastic movement, with the advent of the anti-traditional paradigm of democracy.

Chevrier starts off his second chapter by showing the totalising character of the resolutely antagonistic logic pitting "Westernisation" against "tradition" among the followers of the iconoclastic movement. He pursues his study of the visions of democracy that circulated after the May 4th movement of 1919 by highlighting the metamorphoses and obstacles that arose along the way. At the same time, he underlines the destructured form of democracy accompanied by a distrust of the state among the movement's actors. Finally, Chevrier calls for a reassessment of the Nanjing decade. This period, which clearly constituted a "revolutionary interregnum," has often been approached through the quest for an underlying revolutionary logic. Following other historians' example, Chevrier looks at this period as a dynamic one traversed with several currents of thought. In his conclusion, he situates the studies of democracy in a global context and 
stresses the need to avoid seeing its history in terms of Westernisation.

In the next chapter, Michel Bonnin considers democracy's place in the Communist Party's discourse and practice of democracy from its founding until 1989. He shows how the notion was instrumentalised several times, notably during the Cultural Revolution and its aftermath. He also takes stock of the questioning of democracy by Red Guards and of their understanding of the term in the context of limited access to works on the subject. Their reflections are seen by many as the product of their experiences as well as of their readings of Marx. Bonnin stresses that the democratic aspiration remains alive in China and that it has evolved greatly in content since 1973, influenced by diverse movements that demanded it right up until 1989.

The section, and with it the first part of the book, ends with a text by Zhang Lun entitled "The intellectual, the authorities, and the idea of democracy after Mao: Precept and practice." Zhang Lun is concerned with the situation of intellectuals in China, especially in the post-1978 period. They constitute the "main actors of democracy in China," but in comparison with their Western counterparts, their fate is more complex and painful, and some feel like strangers in their own society. Thus distanced from society, some also experience separation from the state, induced by the unhappy events on Tiananmen Square in 1989. However, some other Chinese intellectuals have since given up all talk and action linked to democracy in response to improvements the regime has made to their material conditions since 1989. Zhang shows how writings on democracy in China have gradually overcome some ideological constraints, such as the prefix "socialist" that peppered the first texts on the subject after the Cultural Revolution. Today, Chinese liberal discourse has a strong constitutionalist ring, in line with what was seen under the first Republic. On the practical plane, Zhang shows that Chinese intellectuals have stressed the development of an urban civil society since 1980 by taking part in elections for deputies to the National People's Congress or at the local level. In passing, Zhang notes the re-emergence of a wholly Chinese intellectual discourse affirming that democracy would be incompatible with "Chinese characteristics." He ends the text by calling attention to distinctions between the existence of Chinese democratic tradition and its actualisation, which faces a series of contextual obstacles. Delmas-Marty opens the fifth section, "Transitions 2," with a chapter on the problems facing the rule of law in a reforming China. She states the elements of the rule of law as conceived and developed, to various degrees, in the West, and then studies their existence and absence or obstacles to their reception in the Chinese context since 1978. She first identifies the factors for consolidation of rule of law in China, notably the reversion to a measure of legality and judicial guarantees. But she also notes the limits to these two developments. Among many destabilising factors, she cites two that have had a critical impact on the development of rule of law in China. On the one hand, there is the larger context of a crisis of democracy and rule of law in the West, and on the other, the general advantage globalisation grants to the economic powers to the disadvantage of universal values. She refutes the contention that China's economic modernisation is gaining strength through the edification of rule of law, but nevertheless urges attention to law reform measures under way.

Stéphanie Balme's chapter is built around the question of relations between the authorities and law in post-Mao China. Her aim is to determine whether the changes she identifies will eventually allow the emergence of rule of law in China, or whether the country will evolve towards a system in which the autonomisation of law continues to pose problems. Adopting the a sociological perspective toward political and judicial institutions, Balme says the Party has created a "legal-rational state" in which law becomes the "ultimate instrument" of legitimisation of the regime that has been in place since the start of reforms. She stresses that the largest number of legislative developments concern various aspects of changes to the planned economy, despite Chinese jurists' sustained interest in constitutionalism. She pays close attention to changes related to the formulation of laws, especially the evolution of the NPC's political role as well as the growing importance of jurists in the legislative process. She takes a prudent attitude toward the issues raised, keeping in mind, among other factors, the Chinese authorities' historic tendency to distrust the individual as a potential threat to state institutions. This still prevalent conception is diametrically opposed to the basis of the rule of law in the West, with its suspicion of state power and the concomitant desire to protect the individual.

Reflections on the rule of law in post-reform China are continued by Leila Choukroune, who examines the issue from the angle of China's WTO entry and its impact on Chinese law in terms of globalisation. She meticulously traces the stakes in the process of China's WTO accession, emphasising that China has had to make the maximum number of concessions in order to gain entry. Choukroune concentrates on the three principles of the second part of the protocol on Chinese accession for the perspectives they might offer for 
the construction of rule of law in China. In particular, to what extent does China's internal judicial order absorb the norms of international law in commercial matters? She takes the position that democracy and rule of law are to be taken together, thus adopting a view contrary to that of Randall Peerenboom. On the first principle, namely uniform application of laws, she underlines the basic difficulties arising from the absence of separation of powers, which leads to local protectionism, among other things. The second principle, transparency of the legal system, comes up against multiple obstacles in its three dimensions, namely elaboration of laws and their publication (i.e. accessibility) and implementation. The third principle, equally compelling, taking into account the state of China's judicial system, is that of the jurisdictional control of administrative acts. Choukroune shows there have been real changes in Chinese administrative law, but their scope is limited in the absence of judicial independence. She concludes by taking a stand against the cultural relativism thesis, according to which the "differentness" of Chinese culture makes it ill suited to the rule of law. She also cautions against overestimating the importance of advances in Chinese judicial reforms, as China's globalisation process remains highly selective.

Delmas-Marty's second contribution deals with the terms of the debate on human cloning in China, the subject of SinoFrench research in which she has actively taken part. If the inclusion of such a subject initially seems surprising, DelmasMarty defends it by stressing that the study of the SinoFrench debates sheds light on basic conceptions of the human being's place and of his or her rights in two very different cultures. The Chinese debate, much like that in France, reflects several positions on both reproductive and non-reproductive cloning, both of which involve ethical issues. Delmas-Marty notes that Chinese researchers are highly conversant with relevant international law, and some invoke the Kantian concept of dignity in setting limits on reproductive cloning. The issue raises highly complex questions that resonate strongly in the Chinese environment, which attaches cardinal importance to the family. China is equally interested for other reasons in non-reproductive cloning. Chinese tradition holds an important place in reflection on this issue, but its reference value is not the same for all researchers. Through the multiple disciplines as well as domains of law involved, this project offers another opportunity to gain a better understanding of alternative points of view.

Jean-Pierre Cabestan, Li Qinglan, and Sun Ping open the sixth section on "New Institutions" with a chapter devoted to the rebirth of the legal profession in China since 1978.
They are concerned with reform of the courts and procuratorates, as well of lawyers' functions. They note the advances made while emphasising, in each case, the limits that members of the legal profession face in the exercise of their functions. These limits are due to insufficient training despite the introduction of competitive exams for judges and lawyers, but above all they are due to political interference in the judicial sphere, which takes several forms and particularly affects judges and lawyers dealing with criminal cases. The authors also draw attention to the unequal distribution of judicial resources, the major urban centres being better served than the countryside. Thus, Chinese litigants experience difficulties in accessing justice, and the prospects of improvement are poor, given the lack of structural and political reforms.

Gunther Schubert continues this section of the book with a reflection on village and township elections. He notes that most Western works on political change in China are based on the premise that the Communist regime will eventually yield place to liberal democracy. This premise constitutes an epistemological obstacle, as it takes too little account of changes underway that bear little relation to an inexorable move towards the rule of law and democracy. Schubert thus chooses a different perspective that examines the potential of village and township elections to promote a form of democracy that could coexist with a one-party system. $\mathrm{He}$ looks at the varied experiences of village and township elections to show how some have in fact helped to stabilise relations between the people and the local authorities, while strengthening the Party's legitimacy, albeit through exercises that did not strictly follow Western democratic norms. Although the current regime does not emerge the winner in every election, the process is on the whole highly positive, as it leads to the selection of competent people enjoying respect among local populations. Meanwhile, Schubert warns against nursing unbridled hopes of a top-down democratisation, stressing the difficulties faced by such an approach. $\mathrm{He}$ concludes with a call to pay closer attention to the countryside when examining political change in China.

Fiorella Allio looks at the role of elections in Taiwan's democratisation process. While noting that many factors were at play in the political changes ushered in since 1987, she says the local electoral process has received insufficient attention in most studies on the island's democratisation and is habitually presented as a result of democratisation whereas, she says, it is a major cause. She retraces the different stages in Taiwan's electoral process since the KMT took power in 1947, suggesting that Taiwan's democratisation be viewed as 
a process resulting from a tacit negotiation between the regime and the increasingly organised opposition forces. This approach refutes those based on foreign intervention or even on an initiative from the top as the sole explanations for Taiwan's political change. In her study on Taiwanese political life, Allio shows that the island's population has had positive views on "values embodied in democracy" right from the time of the Japanese occupation. From this perspective, democracy is seen as being part of "local resources," and stems from a historic evolution that is still underway.

Delmas-Marty has written the concluding chapter, "The Chinese laboratory." Based on the book's diverse contributions, she opens perspectives on several major questions concerning China, emphasising the country's current integration with the international community and that it is in other respects stronger now than at the time it received many Western legal concepts. She stresses the asymmetric character of the reception of Western legal norms, depending on whether the laws concern business or human rights. Chinese resistance to the latter remains strong, despite recent textual advances tending towards their recognition, but this is not an isolated phenomenon on the global scene. Delmas-Marty concludes the chapter, and the book, by calling for a consideration of the Chinese tradition's diverse contributions to legal methods and in international work, so as to rally China towards building a global legal order that attaches as much importance to human rights as to the commercial law norms that are currently favoured.

The variety of disciplines represented by the book's contributors - including history, law, legal history, intellectual history, and political science - enriches this excellent, stimulating, and timely work. Each rigorously documented contribution sheds a highly focused light that helps the reader reflect more deeply on the issues raised.

The sections follow both a chronological and thematic order that is highly appropriate. Some other divisions are possible: The contributions could be regrouped according to whether they present Chinese or Western views and debates over the Chinese tradition. The chapters by Bourgon, Will, Chevrier, and Xiao-Planes invite the reader to identify and then overcome some epistemological obstacles in studying China. They are concerned with better appreciating the major changes taking place in periods in Chinese history too often associated with "immobile Empire," or questioning assumptions of an absence of law in imperial China. Will (on Chinese contributions to the UDHR), Bonnin, Zhang, and Xiao-Planes (in her second contribution) restore Chinese views and debates on central questions such as the place of constitutionalism at the end of Empire and today, the receptivity to human rights among Chinese jurists, and the evolution of writings on democracy (Bonnin, Zhang). These chapters mark another dominant theme of the book that makes the rich reflections of Chinese authors accessible to non-Chinese-speaking readers, along with their often complex underlying contexts.

Another underlying theme of the work lies in the process of internationalisation of Chinese law since the end of Empire. The receptivity to international norms has varied according to the domains of law and the periods. The Chinese contributors to the UDHR clearly had a real desire to work with international norms in human rights matters. Today, while human rights have entered the vocabulary and even Chinese legislation, ${ }^{(2)}$ the interpretation of this concept in China raises many questions, especially given that the Chinese leadership signed on to the 1993 Bangkok Declaration, which affirmed cultural relativism in the matter of human rights. Zhang's contribution mentions discussion with a culturalist flavour among some Chinese intellectuals who maintain that democracy is incompatible with Chinese culture. All these points suggest a need to maintain prudence regarding the circulation of legal norms with respect to human rights in China. At the same time, Choukroune questions the assumption that internationalisation of Chinese law is easier to realise in trade matters by pointing out the numerous obstacles faced. Delmas-Marty's text on the debate surrounding human cloning notes the extensive knowledge of international law on the part of Chinese jurists. The challenge of internationalisation of law in China's reform era takes many forms, given acute sensitivities and structural limits that are unlikely to disappear anytime soon.

The issue of "endogenous resources" has interested Chinese jurists ever since Zhu Suli's 1996 work sparked reflection on the subject. ${ }^{(3)} \mathrm{Zhu}$ in fact launched the debate just when the Party formalised its discussion on "socialist rule of law." Without openly opposing the adoption of laws that nurtured Chinese judicial reforms after 1978, Zhu expressed scepticism over the receptivity to rule of law in China. Actually, his text is better known for the principled position he adopted, namely the need to rely on local paradigms as the

2. Human rights, which were deemed a bourgeois notion in the Maoist period, came in from the cold in 1991 with the first White Paper on the issue. Since then, China has published more White Papers and integrated them into the constitution during its revision in 2004 The White Papers can be read on the following website: http//www.lawinfochina.com.

3. Zhu Suli, "Bianfa, fazhi ji bentu ziyuan" (Changing law, rule of law, and its local resources), in Zhu Suli, ed., Fazhi qi bentu ziliao (Rule of law and its local resources), Beijing, Zhongguo zhengfa daxue chubanshe (Zhengfa University Press), 1996, p. 3. 
bases of legal reform in China. The argument is that local or endogenous resources respond best to the modernisation of Chinese law than models from traditions totally foreign to China, with their different underlying contextual elements. Zhu's call prompted strong reactions, some of which were critical, and others of which extended it in nationalist and essentialist ways. ${ }^{(4)}$ Chinese legal doctrine has over the past 12 years been characterised by a veritable debate. ${ }^{(5)}$ There is a clear desire for revalidation of Chinese tradition, especially in the legal area, which is perceived as being unjustly neglected in favour of the importation of Western legal rules and institutions. ${ }^{(6)}$

In other words, this debate conceals an important dimension of identity, the terms of which, in the eyes of Chinese jurist, affects China's relations with the West. Although at first there were few practical suggestions of local paradigms as the debate continued to focus on Chinese judicial reforms based on adoption of laws from abroad, the discussion has since been enriched in precise and diverse ways. ${ }^{(7)}$ It would therefore have been interesting for the book to include a contribution on this issue, which remains current in China and directly concerns Chinese tradition. ${ }^{(8)}$

Another theme on which the book could have surveyed more developments is that of the Confucian revival underway in China since the early 1990s. Cheng's text gives a good perspective of the origins and prospects of this neoConfucianism, with Tu Wei-Ming as leader, but the reader is left wishing for more regarding the growing impact of "Confucianism" on China today. ${ }^{(9)}$ Moreover, many authors, both Chinese and Western, who don't necessarily subscribe to this neo-Confucianism, have said that some elements of Confucianism could help the cause of democracy and especially of legal reform. ${ }^{(10)}$
This work is a decisive contribution, indispensable to anyone interested in China and its complex relations with the West. One hopes that others will be inspired by its example and follow up on the impressive work done by the book's editors and all of its authors.

\section{- Translated by N. Jayaram}

4. As examples of essentialist and nationalist versions, see Guo Zhong, "Lun dangdai Zhongguo shehui zhuanxing shiqi: Falü de shehui jingshen jichu " (The spirit and socia bases of law in the social tranformation of modern China), Faxuejia, $n^{\circ} 4,2006$, p. 77. Guo Zhong says China is seeing a crisis of confidence in law, which according to him was an unknown phenomenon so long as Confucianism was the basis of Chinese law and reigned uncontested as the spiritual base of Chinese society. He denounces the belief he attributes to all Chinese jurists, according to which foreign judicial models could inspire ongoing reforms. Nowhere does he mention the diverse problems of current Chinese judicial system, which easily account for the crisis of confidence he evokes, rather than the "foreign" nature of Chinese reforms.

5. For recent instances of responses to Zhu Suli, see among others: Sang Benqian, "'Fazhi qi bentu ziliao': Jianping Suli 'bentu ziliao" shuo" (On "Fazhi qi bentu ziliao": A response to Zhu Suli on the subject of local paradigms), Faxuejia, $n^{\circ} 1,2006$, p. 3. Deng Zeng Lai, "Zhongguo faxue xiang he chu qu? Dui Suli 'Bentu Ziliao Lun' de pipan" (Where is Chinese legal theory headed? A critical reply to Zhu Suli's discussion on local resources), Zhengfa Luntan, $\mathrm{n}^{\circ} 3$ (2005), p. 52.

6. It is a complex question. The surrounding nationalist context could partly explain such statements, but clearly most of the research by jurists on Chinese judicial reforms are concerned with foreign models, whether in international law, civil law, or common law.

7. See Xie Hui, "Xifang bei jing xia Zhongguo gudian falü jiejue de yiyi" (The significance of the interpretation of ancient Chinese law in relation to Western culture), Xiandai Faxue, $n^{\circ} 5,2004$, p. 29. On p. 30, Xie Hui says Chinese tradition is treated "like rubbish" and proposes recourse to techniques of interpreting "ancient" (meaning imperial era) Chinese law as a local paradigm to nurture judicial reforms underway since 1978. In another text, he suggests recourse to custom (which he distinguishes from codified customary law). See Xie Hui, "Shu lun minjian guifan dui falü fangfa de keneng gongxiang" (Discussion on the possible strengths of customary law in the judicial method), $X i$ andai Faxue, $n^{\circ} 5,2006$, p. 28. Recourse to some elements of Daoist thought is also included in the paths explored: Long Daxuan, "Dao yu Zhongguo falü chuantong " (Dao and the Chinese judicial tradition), Xiandai Faxue, $n^{\circ} 2,2004$, p. 54.

8. Ma Jianyin, "Falü yizhi de kunjing: Xiandaixing, quanqiuhua yu Zhongguo yujing " (Dilemmas of transfers: Modernity, globalisation and Chinese context), Zhengfa Luntan, $n^{\circ} 2,2008, p .54$. In this rich article, the author traces the history of the transfer of law in China since the late Qing era (p. 55) and suggests that future transfers of law take better account of local realities (bentu shehui) in order to ensure that transferred laws don't remain dead letters or even clash with the values of that society (p. 64).

9. Daniel Bell, China's New Confucianism: Politics and Everyday life in a Changing Society, Princeton, Princeton University Press, 2008. Bell explains the context of the renewal and points out, on pages $9-11$, how the Party has benefited from the process. Xu Zhangrun, "Heping yu chongtu: Zhongguo mianlin de liu da wenti - Yi wei hanyu wenming faxue congyezhe de minzuzhuyi wenben" (Peace and conflict: Six questions Chine faces - Nationalist text by a legal professional in Chinese civilisation), Zhengfa Luntan, $n^{\circ} 6,2005$ p. 94. On page 106, Professor Xu launches into a lively plea for a new humanist Confucianism as source of legal reform. Guo Zhong also supports a recourse to Confucianism. In rather general terms his proposal, as a remedy to the crisis he speaks of, is a rehabilitation of Confucianism, especially li and ren, or well-being.

10. William P. Alford, "A Second Great Wall? China's Post-Cultural Revolution Project of Lega Construction," Cultural Dynamics, vol. 11, n² 2, 1999, p. 193. Alford, in a brief survey of Chinese tradition, cites as an example the "imputability of leaders which comes with Confucianism, in view of the virtue exigency that is attached to their function"; Yu Ronggen, "Xunqiu 'Zhong Dao': Rujia zhi Fa de jingshen yu qi pushi jiazhi" (In search of the Golden Mean: The spirit of Confucian law and its universal value) Xiandai Faxue, $n^{\circ}$ 6, 2006, p. 66. Hu Renzhi, "Kongzi 'YiLi' guan yu xiandai fazhi hehun linian" (Confucian concepts of $\mathrm{Yi}$ and $\mathrm{Li}$ and their contribution to the reflection on harmony), Xiandai Faxue, $n^{\circ} 4,2006$, p. 181 